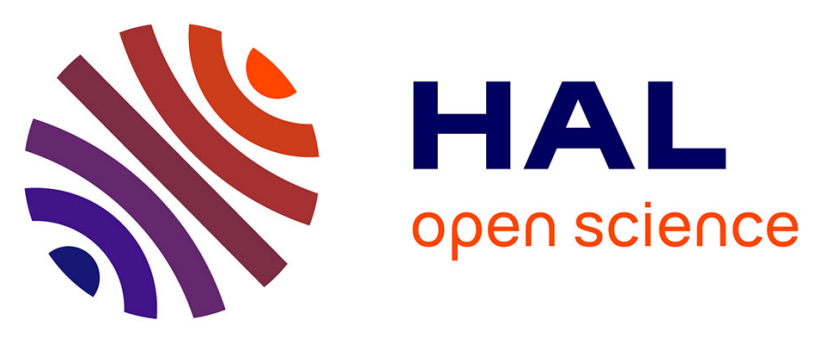

\title{
Influence of Quality and Productivity on Milk Production Sustainability: From an Anthropocentric to an Ecocentric View
}

Max W. Oliveira, Feni Agostinho, Cecília Almeida, Biagio F. Giannetti

\section{To cite this version:}

Max W. Oliveira, Feni Agostinho, Cecília Almeida, Biagio F. Giannetti. Influence of Quality and Productivity on Milk Production Sustainability: From an Anthropocentric to an Ecocentric View. IFIP International Conference on Advances in Production Management Systems (APMS), Sep 2016, Iguassu Falls, Brazil. pp.423-430, 10.1007/978-3-319-51133-7_50 . hal-01615752

\section{HAL Id: hal-01615752 \\ https://inria.hal.science/hal-01615752}

Submitted on 12 Oct 2017

HAL is a multi-disciplinary open access archive for the deposit and dissemination of scientific research documents, whether they are published or not. The documents may come from teaching and research institutions in France or abroad, or from public or private research centers.
L'archive ouverte pluridisciplinaire HAL, est destinée au dépôt et à la diffusion de documents scientifiques de niveau recherche, publiés ou non, émanant des établissements d'enseignement et de recherche français ou étrangers, des laboratoires publics ou privés.

\section{(c)(1)}

Distributed under a Creative Commons Attribution| 4.0 International License 


\title{
Influence of Quality and Productivity on Milk Production Sustainability: from an Anthropocentric to an Ecocentric View
}

\author{
Max W. Oliveira ${ }^{1,2 \star}$, Feni Agostinho ${ }^{2}$, Cecília M.V.B. Almeida ${ }^{2}$, and Biagio \\ F. Giannetti ${ }^{2}$ \\ 1 Federal Institute of Sul de Minas Gerais, Inconfidentes, Brazil \\ 2 Paulista University, São Paulo, Brazil \\ feni@unip.br
}

\begin{abstract}
Brazil ranks fourth worldwide position on milk production, and Minas Gerais State corresponds to $27 \%$ of national production. Eighty percent of the Brazilian milk producers are extensive-familiar, characterized by the absence of technicization and inefficient management that leads to low productivity and quality. Aiming to improve milk productivity and quality, the governmental program "Minas Leite" was launched. This work aims a regional sustainability multicriteria assessment of milk production in Minas Gerais. Social, economic, and environmental indexes are calculated before and after implementing "Minas Leite". Results show that "Minas Leite" should be promoted because it leads to higher sustainability than current production (2.3 times more liters of milk per year, 8.9 times more annual net income, $52 \%$ more available jobs, and an increase of $13 \%$ on salaries paid). However, efforts are needed to reach a regional strong sustainability under an ecocentric perspective, because "Minas Leite" showed worst performance for environmental indicators.
\end{abstract}

Keywords: Milk Production . "Minas Leite" Program · Minas Gerais State $\cdot$ Sustainability.

\section{Introduction}

Cow milk, a source of protein, vitamins, minerals and energy is amongst the most consumed food items worldwide. Brazil holds the fourth position in the world milk production ranking, accounting for $5.3 \%$ of the overall production, below to the United States (14.7\%), India (8.6\%) and China (6\%) [1]. The milk production chain currently holds a social and economic importance in Brazil, because it employs nearly three million workers and produces annually 35 billion liters of milk; in 1990 this value was 19.5 billion and the goal is to reach 41 billion in 2023 [2]. The state of Minas Gerais is the number one milk producer in Brazil, accounting for $27 \%$ of the total national production [3].

\footnotetext{
* We are grateful to CAPES and CNPq
} 
Some characteristics of the dairy farming in Brazil are its distribution all over the country, the heterogeneousness among the productive systems, and a considerable participation of small family producers on the national yield. According to Carvalho [4], until the 90's there was a national interventionism on every stage of the milk productive chain, which caused a standardization on the dairy products. For the industry, this interventionism discouraged the willingness of the market to develop new products, bringing to the consumer a restricted range of dairy products. However, this government policy were considered as positive for the producers, as they would know in advance how much they would receive for the milk produced. After the trade opening occurred between 1990 and 1992, the prices were then ruled by the market law of supply and demand.

Aiming to modernize and increase the competitiveness of the milk productive chain, the Brazilian government approved the Normative Instruction no.51 in 2002, which determined the minimum quality standards for the raw milk (in natura). This corresponded to a major pressure on the producers, as they were forced to fit in those new standards under penalty of being excluded of the market [5]. According to CEPEA [2], from these changes and considering the new food requirements for the consumers, a different business behavior for milk producers and for the entire milk chain agents were also required. All these changes led to another pressure on the producers, for higher specialization, adoption of new technologies, increase of production, decrease of seasonality, improvement of the product and increase on the production scale.

Brazil currently has highly technified productive systems (such as the Fazenda Colorado in the municipality of Araras that produces 62,000 $\mathrm{L}_{m i l k}$ /day [6]), but about $80 \%$ of the producers has low level of intensification and production $(<$ $200 \mathrm{~L}_{\text {milk }} /$ day; [7]). This majority, called as small family producers, faces many technical and economic difficulties to keep their production, which demands for governmental support as financing and technical assistance. CEPEA [2] shows, for example, that meanwhile the effective operational cost of the milk production in the state of Minas Gerais increased $1.86 \%$ between November 2014 and December 2015, the average price paid for the producer in 2015 was the lowest in the last five years, reaching only 0.95 BRZ. Another difficulty faced by the small producer is the increase of the volume and quality for the milk produced, because the dairy houses pay more for producers who provide higher volumes of milk with higher nutritional and better sanitary conditions.

On the effort to overcome these liabilities and avoid other potential socioeconomic problems that would raise if the small producers gave up producing milk (rural exodus, for example), the government of Minas Gerais launched in 2005 the Milk Productive Chain State Program, known as "Minas Leite". The goal of this program is to enable the small-family milk production by providing technical and management qualification focused on their productive systems, aiming the increase of productivity, quality of milk, and producer income. Although this program can be considered as positive on the short term politics, creating public policies such as the "Minas Leite" rarely consider a systemic view of the issue (i.e. in different scales), which may result in additional problems for a larger 
scale perspective. For example, what would be the impact on the sustainability of the regional milk production of implementing the "Minas Leite" program?

This work aims to use a multimetric approach to assess the regional sustainability of milk production in southern Minas Gerais. Environmental, social and economic indexes are analyzed to discuss on the regional sustainability of the current yearly milk production, as well as after the intensification of extensive systems as envisioned by the "Minas Leite" program.

\section{Methods}

\subsection{Case Study Description and Raw Data Source}

The environmental performance of the productive systems analyzed in this work were previously studied by Oliveira and Agostinho [8]. These authors considered 92 milk producers by obtaining raw data in situ (through personal interviews and local observations), and through cluster analysis that resulted in five representative systems - shown on Table 1. G1 and G2 are rated as semi-intensive, they have Dutch cattle created in good grazing quality, in addition to feeding supplemented with fodder and feed. G3 is an extensive system, it has cattle with not genuine genetics created in degraded grazing with forage supplement during winter. The G4 and G5 are intensive systems, they have Dutch cattle that are confined in sheds (free stall model) and are fed with feed and fodder during the year; the facilities have high technology (i.e. extraction and pre-processing of milk, as well as thermal comfort for animals). Greater details on the characteristics of the systems and on the criteria used for the cluster analysis are shown in Oliveira and Agostinho [8].

Table 1. Main characteristics of milk production systems existing at southern region of Minas Gerais State

\begin{tabular}{|c|c|c|c|c|}
\hline System & $\begin{array}{c}\text { Area } \\
\text { (ha) }\end{array}$ & $\begin{array}{l}\text { Production } \\
\text { (Lmilk/day) }\end{array}$ & $\begin{array}{c}\text { Productivity } \\
\text { (Lmilk/cow/day) }\end{array}$ & $\begin{array}{c}\text { Regional repre- } \\
\text { sentativeness }^{a}(\%)\end{array}$ \\
\hline G1 (semi-intensive) & 182 & 4.400 & 21 & 1 \\
\hline G2 (semi-intensive) & 19 & 360 & 12 & 17 \\
\hline G3 (extensive) & 17 & 36 & 5.5 & 80 \\
\hline G4 (intensive) & 21 & 1060 & 21 & 1 \\
\hline G5 (intensive) & 99 & 3500 & 31 & 1 \\
\hline
\end{tabular}

${ }^{a}$ Percentage of total regional area $(600,000 \mathrm{ha})$ allocated to milk production

\subsection{Indices on Milk Production Sustainability}

The meaning of sustainability in this paper consider the traditional conceptual model in which the importance of social, economic and environmental aspects 
are acknowledged to ensure that the current society develops without negatively affecting the capacity of future generations to have their needs assisted. The indexes chosen and considered as representative of sustainability concept, for the purposes of this work, are shown on Table 2. The economic and social indexes were established after identifying those that are most used and accepted by the scientific community and governmental research agencies focused on milk production studies; additionally, experts on technical issues related to livestock were consulted to validate the chosen indexes. Concerning the environmental aspects, among a wide variety of tools and indexes available on the literature that assess the pressure on environment caused by productive systems, in this work we have used the environmental accounting based on emergy (spelled with "m"). This method was chosen due to its strong scientific background, it is based on the energy of biological systems, the general theory of systems, and the thermodynamics. Details regarding definitions, meanings and rules for the environmental accounting using emergy can be found mainly in Odum [9]. Among the indexes derived from this method, it were chosen those which expressed directly the environmental sustainability of the systems analyzed: emergy renewability index $(\% \mathrm{R})$ and environmental sustainability index (ESI).

Table 2. Social, economic and environmental indicators

\begin{tabular}{lll}
\hline \multicolumn{1}{c}{ Indicators } & \multicolumn{1}{c}{ Legend } & \multicolumn{1}{c}{ Meaning } \\
\hline \multirow{2}{*}{ Social } & hlabor/yr & Hour of labor per year; \\
& BRZ/hlabor & $\begin{array}{l}\text { Income received (in Brazilian currency) } \\
\text { per labour hour; }\end{array}$ \\
& Lmilk/yr & Liters of milk produced per year; \\
Economic & BRZ/Lmilk & Net income per liter of produced milk; \\
& $\% \mathrm{R}$ & Emergy renewability index (renewable \\
Environmental & ESI & emergy/total emergy); \\
& & Environmental sustainability index. \\
\hline
\end{tabular}

The indexes on Table 2 were initially calculated for each individual group as presented in Table 1 (G1, G2, G3, G4 and G5), what allows a comparison among groups concerning their social, economic and environmental performance. Next, the indexes obtained for each group are expanded for all the southern Minas Gerais area; for this purpose, the regional representativeness (\% in land use, Table 1) of each group is considered. This scenario is called as Scenario\#0, which allows the discussion about the current sustainability of regional milk production. At the same time, the indexes obtained for each group are expanded again for the entire southern region of Minas Gerais, but now considering the complete replacement of the extensive systems G3 by the semi-intensive system G2 as envisioned by "Minas Leite" program. This scenario is called as Scenario \#1, which allows a discussion about a potential sustainability "if" the "Minas Leite" program were implemented; the potential distribution of milk production groups 
in Scenario \#1 becomes G1 (1\%), G2 (97\%), G3 (0\%), G4 (1\%) and G5 (1\%). Exclusively for the indicator income received per hour of labor $\left(\mathrm{BRZ} / \mathrm{h}_{\text {labor }}\right)$, the average value was considered for both Scenario \#0 and \#1 instead of an expansion using hectares as for all other indicators. This consideration was performed due to existing conceptual issues regarding the use of area units in expanding the $\mathrm{BRZ} / \mathrm{h}_{\text {labor }}$ indicator in the entire region, which could mislead important information and result in non-precise numbers.

\subsection{Graphical Representation for Sustainability Indicators}

The indexes considered in this study to assess the sustainability of milk production in southern region of Minas Gerais State have different dimensions and scales, which hampers a direct assessment. According to Ulgiati et al. [10], this difficulty can be overcome by applying normalization techniques on indicators, which allows comparison among them. From other options, the normalization based on the total impact generated is used in this work as described: the value of each index is divided by the sum of the same indexes obtained by the two scenarios. Next, the normalized indexes are shown in a radar chart type for easier interpretation. Considering that every index (economic, social and environmental) have the same importance (or weight) in representing the sustainability concept, the biggest area shown on the graph indicates the scenario with the greatest sustainability.

\section{Results and Discussion}

\subsection{Sustainability Study for the Assessed Milk Production Groups}

Table 3 shows the social, economic and environmental indexes for the assessed milk productive groups. When comparing one another, G3 has the lowest production, lowest labor demand, lowest compensation for the employee, and a negative net income - the economic survival of this group is due to its other products and services traded, excluding milk production. These indexes corroborate with the results obtained by Oliveira et al. [11], Buainain [12], Rodrigues et al. [13] and Fassio et al. [14], which justify the low socio-economic performance of group G3 due to the low efficiency on production management and the need for its intensification through better facilities, herds, technical and management knowledge. On the other hand, G3 shows the best results for environmental indexes, achieving a renewability of $24 \%$ and an environmental sustainability index of 0.66 , even though the ESI values lower than 1 leads to low sustainability according to Brown and Ulgiati [15] criterion.

Even though it is rated as an intensive management that usually means an economically powerful system, G4 shows to be economically inefficient with a net loss of $0.24 \mathrm{BRZ}$ per liter of produced milk. This characteristic existing in some intensive systems was also noticed and discussed by Santos et al. [16], who argues that inefficient management of systems with high intensification 
Table 3. Social, economic and environmental indicators obtained by the assessed milk production groups

\begin{tabular}{llccccc}
\hline Indicators & Legend & G1 & G2 & G3 & G4 & G5 \\
\hline \multirow{2}{*}{ Social } & hlabor/yr & 19,36 & 5,06 & 2,64 & 9,68 & 14,52 \\
& BRZ/hlabor & 6.18 & 3.01 & 2.47 & 5.39 & 5.99 \\
Economic & Lmilk/yr & $1,606,000$ & 131,4 & 12,045 & 386,9 & $1,277,500$ \\
\multirow{4}{*}{ Environmental } & BRZ/Lmilk & 0.50 & 0.52 & -0.51 & -0.24 & 0.19 \\
& ESI & 8.79 & 12.36 & 24.64 & 3.07 & 3.47 \\
& & 0.11 & 0.17 & 0.66 & 0.03 & 0.04 \\
\hline
\end{tabular}

(e.g. the waste of inputs and inadequate handling of herd) also lead to low economical indexes, which means that intensification should not be considered as synonymous with high economic performance. On the other hand, although G2 is classified as a semi-intensive system (i.e. less intensive than G4), it has an adequate technology and applies an efficient management on production, which results in higher net income than G4 and G5. This was also identified and discussed by Souza and Buainain [5] that relate economic performance with the synergy among different activities within system, public policies that enable the incorporation of technologies with technical assistance, as well as the access of producers to technology and information.

Table 3 stresses that the intensification of the productive system may lead to an increase on the productivity - and maybe on the quality [17] - of milk produced, which also reflects in better socio-economical indexes. However, the intensification of productive systems demands higher quantity of global resources (material and energy), that are usually comes from outside of system boundaries and are often fossil-based (i.e. non-renewable resources). Thus, the intensification may result on reducing the environmental performance because additional non-renewable global resources are necessary to maintain and/or increase the intensification of milk production systems.

\subsection{Regional Sustainability of Milk Production}

Figure 1 notices that scenario \#0 shows better performance for both environmental indexes (\%R and ESI), while scenario \#1 shows better performance for the socio-economical indexes. A decrease of $36 \%$ on the use of renewable resources was obtained on \#1 compared to \#0 because the intensification of the productive systems presupposes higher requirements of external resources, decreasing its resilience over the pressures from the market and its renewability; this is also the reason for the decrease of ESI value. This behavior was also identified by Giannetti et al. [18] that stressed the decay on the performance of emergy indexes for Brazil, taking into consideration a scenario in which there is a decrease on the use of renewable resources and an increase of the dependency on non-renewable resources. The productivity increase is usually linked to the 
increase of demand for external resources, which results in a worse environmental performance.

Concerning the economical indexes, Figure 1 shows: (i) higher regional milk production (2.3 times more Lmilk/yr) for \#1 compared to \#0, which results in a net income 8.9 times higher; (ii) the higher quality and quantity of milk produced on \#1 leads to higher selling price than \#0, which is the reason why net profit increases in a proportion higher than the milk production. Even to a lesser extent, the same behavior occurs for the social indexes: (i) for $\# 1$, the region would demand higher amount of laborhours (i.e. it provides approximately $52 \%$ more jobs); (ii) \#1 rewards better the employee (income 13\% higher) which supports a stronger regional economic performance. These results are in accordance with those obtained by Tupy and Primavesi [19], in which the most intensified systems usually yield more milk, require more qualified employees, and are able to pay better salaries. Finally, an overview of all indicators present in Figure 1 leads to a higher area obtained by \#1, which means higher sustainability in accordance to methodological approaches considered in this work; in this sense, the "Minas Leite" program.

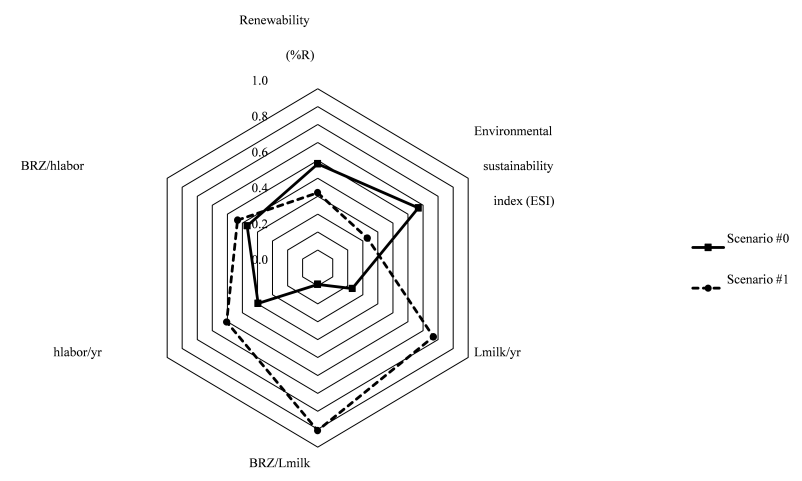

Fig. 1. Comparison among social, economic and environmental indicators

\section{Conclusions}

A local perspective analysis show that G3 (family-extensive) has the worst socioeconomic performance, as it provides lower amount of jobs per year $(2,640$ hlabor/yr), pays lower salaries (2.47 BRZ/hlabor), has lower milk production ( $12,045 \mathrm{Lmilk} / \mathrm{yr})$, and has a negative net income ( $-0.51 \mathrm{BRZ} / \mathrm{Lmilk})$. On the other hand, G3 shows the best environmental indexes, achieving $24 \%$ of renewability and 0.66 for environmental sustainability index. A trade-off between socio-economic and environmental aspects is evident, which claims for efforts towards production systems intensification with reduced demand for external and non-renewable resources. 


\section{References}

1. Food and Agriculture Organization: http://www.fao.org/docrep/018/i3107e/ i3107e00.htm

2. Center for Advanced Studies in Applied Economics: http://www.cepea.esalq. usp.br

3. Brazilian Institute of Geography and Statistics: http://www.ibge.gov.br/home/ estatistica/pesquisas/pesquisa_resultados.php?id_pesquisa=21

4. Carvalho, G.: A Indústria de Laticínios no Brasil: Passado, Presente e Futuro. Embrapa Gado de Leite, Juiz de Fora (2010)

5. Souza, R.P., Buainain, A.M.: A Competitividade da Produção de Leite da Agricultura Familiar: Os Limites da Exclusão. Estudos Sociedade e Agricultura 2, 308-331

6. Milkpoint: http://www.milkpoint.com.br/top100/2015/EBO0K-TOP100.pdf

7. Zoccal, R.: Quantos são os produtores de leite no brasil?, http://www.cileite. com.br/content/panorama-do-leite

8. Oliveira, M.W., A.F.: Assessing Alternative Developments for Milk Production in the Southern Region of Minas Gerais State, Brazil: An Emergy Perspective. In: 8th Biennal Emergy Research Conference. pp. 237-246. University of Florida, Gainesville (2015)

9. Odum, H.T.: Environmental Accounting. Wiley, Hoboken (1996)

10. Ulgiati, S., Ascione, M., Bargigli, S., Cherubini, F., Franzese, P., Raugei, M., Viglia, S., Zucaro, A.: Material, Energy and Environmental Performance of Technological and Social Systems Under a Life Cycle Assessment Perspective. Ecological Modelling 222(1), 176-189 (2011)

11. Oliveira, N., Aleixo, A., Sato, S., Junkes, M., Habitzreuter, P.: Práticas Produtivas da Agricultura Familiar: Um Estudo no Município de Espigão D’Oeste, RO. In: X Congresso Internacional de Administração, Gestão Estratégica, Tecnologia do Impacto nas Organizações. Ponta Grossa (2015)

12. Buainain, A. M.: Alguns Condicionantes do Novo Padrão de Acumulação da Agricultura Brasileira. In: Buainain, A.M., Alves, E., Silveira, J.M., Navarro, Z. (eds.) O Mundo Rural no Brasil do século 21, pp. 213-240. Embrapa (2014)

13. Rodrigues, M.H.S., Souza, M.P., Rodríguez, T.D.M., Aguiar, I.S., de Souza Rodrigues, E.F.: Análise de Eficiência dos Produtores de Leite do Município de Rolim de Moura, no Estado de Rondônia. Gestão \& Regionalidade 27(79), 61-76

14. Fassio, L.H., Reis, R.P., Geraldo, L.G.: Desempenho Técnico e Econômico da Atividade Leiteira em Minas Gerais. Ciência e Agrotecnologia 30(6), 1154-1161 (2006)

15. Brown, M.T., Ulgiati, S.: Emergy Analysis and Environmental Accounting. Encyclopedia of energy 2, 329-354 (2004)

16. Santos, J.A., da Cruz Vieira, W., dos Santos Baptista, A.J.M.: Eficiência Técnica em Propriedades Leiteiras da Microrregião de Viçosa-MG: Uma Análise NãoParamétrica. Organizações Rurais and Agroindustriais 7(2) (2011)

17. Brazilian Agricultural Research Coporation: https://sistemasdeproducao. cnptia.embrapa.br/FontesHTML/Leite/LeiteSudeste/introducao.html

18. Giannetti, B., Demétrio, J., Bonilla, S., Agostinho, F., Almeida, C.: Emergy Diagnosis and Reflections Towards Brazilian Sustainable Development. Energy policy 63, 1002-1012 (2013)

19. Tupy, O., Primavesi, O.: Avaliação dos Impactos Econômicos, Sociais e Ambientais de Tecnologias da Embrapa Pecuária Sudeste. Embrapa Pecuária Sudeste, São Carlos (2006) 